American Journal of Economics and Business Administration 3 (4): 596-603, 2011

ISSN 1945-5488

(C) 2011 Science Publications

\title{
Cost Efficiencies and Rankings of Flagship Universities
}

\author{
G. Thomas Sav \\ Department of Economics, \\ Raj Soin College of Business, \\ Wright State University, Dayton, 45440, Ohio
}

\begin{abstract}
Problem statement: Each state in the U.S. touts a premier university as the flagship of its publicly funded higher education system. With decreased government budgets and increased interest in public management reforms, these institutions are being pressured to provide evidence of and set examples for ever greater improvements in operating cost efficiencies. The problem, however, is that empirical measures of their efficiencies or inefficiencies can be sensitive and, therefore, vary widely depending upon the underlying model specification. Approach: The study used stochastic frontier analysis to estimate university cost inefficiencies over the 2005-09 academic years. Transom and Cobb-Douglas specifications were combined with two inefficiency models that treated university environmental factors as inefficiency determinants and as cost determinants. University inefficiency rankings were provided on the basis of mean scores and compared to the rankings obtained under the alternative models. Results: University mean inefficiency scores were estimated to vary between 1.19 and 1.32, indicating that costs were on average between 19 and $32 \%$ above the minimum frontier costs. At the individual university level, inefficiencies ranged from 1.015-2.43. Two specifications indicate that efficiency improvements occurred in the 2008-09 academic year. A university ranking of mean scores indicated an $87 \%$ difference between the most and least inefficient university. There was substantial sensitivity of rankings to model choice, but university rank status was found to be most unstable in the middle of the ranking distribution. Conclusion: The findings offer caution in proceeding to stochastic frontier estimates of inefficiencies without careful consideration and investigation of the sensitivities of such estimates to model choices. This study showed that advice is applicable, at least, to inefficiency estimates of U.S. flagship universities. Whether or not it is applies equally to other groups of universities is a matter of consideration for future studies.
\end{abstract}

Key words: Integrated Postsecondary Education Data System (IPEDS), inefficiency estimates, mean inefficiency scores, careful consideration, ranking distribution

\section{INTRODUCTON}

This study provides cost inefficiency estimates for publicly funded flagship universities in the United States. For each state in the U.S., these universities represent the premier public tax payer funded institutions for the state's higher education system. They are generally the state's largest producer of undergraduate education, graduate education and scholarly output and, relative to other state colleges and universities, receive larger budgets and funding priorities under discretionary allocations. However, in terms of managing their university resources, some state flagship might be more cost efficient or inefficient than those in other states. Given the state government budget tightening belts brought about by the global financial crisis and the long term pressure likely to be brought to bear on higher education funding, there should be public and managerial interest in the efficiency with which these flagship universities operate. The present study is believed to be the first to provide this type of efficiency inquiry for this group of universities.

The methodology employs stochastic cost frontier analysis using panel data for individual universities. The panel spans four academic years of available data, 2005-09. The university cost inefficiency is estimated as cost incurred above the minimum cost frontier. Thus, inefficiency estimates can produce scores that range from one to potentially infinity. The estimates, however, can depend upon specific formulations. In the present study, the sensitivity of inefficiency estimates is provided under the econometric implementation of a transom and Cobb-Douglas cost structure. Those are combined with two inefficiency models: one being the 
Battese and Coelli (1995) model in which university specific environments and characteristics are implanted in the inefficiency determination and the second being the Battese and Coelli (1992) model in which these covariates enter the cost structure. Inefficiency estimates under each specification-model are provided for the aggregate group of universities over the total four academic years and for each individual academic year. In addition, a mean inefficiency is calculated and used to provide an inefficiency ranking of universities. That ranking is also compared to the individual university ranking achievements under each of the four econometric cost and inefficiency specifications and models.

\section{MATERIALS AND METHODS}

The methodology used in this study rests with the stochastic frontier model attributed to Aigner et al. (1977); and Meeusen and Broech (1977) and further developed in the use of panel data by Battese and Coelli (1992) and Battese and Coelli (1995). Many of the added theoretical contributions that are beyond the scope of the present study are comprehensively available in Kumbhakar and Lovell (2003); Coelli (2005) and Fried et al. (2008). In addition, one can easily access the numerous industrial applications, including, for example, empirical studies of U.S. dairies (Kumbhakar et al., 1991), U.S. airlines (Kumbhakar, 1991), India paddy farms (Battese and Coelli, 1992; 1995), the U.S. insurance industry (Cummins and Weiss, 1993), international airlines (Coelli et al., 1999), U.S. hospital care (Bradford et al., 2001) Japanese hospitals (Fujii, 2001), Taiwan banking (Huang and Wang, 2001), U.S. electricity (Knittel, 2002), Switzerland nursing homes (Farsi and Filippini, 2004), British railways (Mulatu and Crafts, 2005), Lisbon crime prevention (Barros and Alves, 2005) and English football (Barros and Leach, 2007), among many others.

For the specific interest of this study, only five empirical applications to higher education were in existence at the outset of this research. Izadi et al. (2002) estimated inefficiencies for 99 British higher education institutions, Stevens (2005) did so for 80 English and Welsh universities, Johnes and Johnes (2009) also for English institutions, McMillan and Chan (2006) for Canadian universities and Abbott and Doucouliagos (2009) for New Zealand and Australian. Two of the studies are cross sectional instead of panel related, the sample sizes vary from 7-121 universities and the number of variables used ranges from 4 to over 50. Moreover, each study uses different cost specifications and applies different inefficiency models. And although McMillan and Chan (2006) make useful comparisons between nonparametric data envelopment estimates and stochastic frontier estimates, none of studies undertake comparative evaluations of cost specifications to inefficiency models. None of the studies included U.S. universities.

Among all the empirical implementations, most stochastic frontier analyses have relied upon the translog and Cobb-Douglas forms of production and cost. In this study, the multi product nature of universities requires the superiority of the cost function specification. Moreover, given that the Cobb-Douglas is nested within the translog, the university Cost (C) can be conveniently specified as Eq. 1 follows:

$$
\begin{aligned}
& \operatorname{InC}_{\mathrm{it}}=\alpha_{0}+\sum_{\mathrm{j}} \alpha_{\mathrm{j}} \operatorname{In} \mathrm{Y}_{\mathrm{it}, \mathrm{j}}+\sum_{\mathrm{k}} \alpha_{\mathrm{k}} \operatorname{InP}_{\mathrm{it}, \mathrm{k}} \\
& +\frac{1}{2} \sum_{\mathrm{j}} \sum_{1} \alpha_{\mathrm{jl}} \operatorname{In} Y_{\mathrm{it}, \mathrm{j}} \operatorname{InY} \mathrm{it}_{\mathrm{it}, \mathrm{l}}+\frac{1}{2} \sum_{\mathrm{k}} \sum_{\mathrm{m}} \alpha_{\mathrm{km}} \operatorname{InP}_{\mathrm{it}, \mathrm{k}} \operatorname{InP}_{\mathrm{it}, \mathrm{m}} \\
& +\sum_{k} \sum_{j} \alpha_{k j} \operatorname{InP}_{i t, k} \operatorname{In} Y_{i t, j}+\left(v_{i t}+u_{i t}\right) i=1, \ldots, N t=1, \ldots, T
\end{aligned}
$$

where, in the special case of the Cobb-Douglas specification, the cross product terms are eliminated. For the $\mathrm{N}$ universities and $\mathrm{T}$ academic years, outputs and input prices are represented by the $\mathrm{Y}_{\mathrm{j}}$ and $\mathrm{p}_{\mathrm{k}}$, respectively. The actual variables used to measure such outputs and prices are dependent upon data availability but have generally included various measures of education and research outputs along with a faculty wage for an input price.

The error term is a composed of the stochastic error $v_{i t}$ and a one-sided error $u_{i t}$ representing the inefficiency of the individual university. The former is the usual white noise associated with measurement error and random events that impose upon the university but are externally determined. Random events come in many forms, including, for example, labor strikes and destructive earthquakes. As is usual, it is assumed that the $v_{\text {it }}$ are independently and identically distributed with zero mean and variance $\sigma_{v}{ }^{2}$. Inefficiency, on the other hand, is the potential cost increasing component that can arise from university characteristics or environments as well as managerial decision-making. Among other things, administrative and faculty governance decision-making can determine the specific characteristics related to the university's student body and faculty. In addition, different universities can operate under different government environments. Any number of such characteristics and environments can potentially create inefficiencies such that $\mathrm{u}_{\mathrm{i}} \geq 0$ and, therefore, university operating costs are pushed above the minimum obtainable frontier. However, there are varying assumptions regarding the distributional 
properties of the inefficiency term and how university characteristics and environments are modeled with regard to the stochastic frontier. Two such efficiency models include the widely adopted Battese and Coelli (1992; 1995) specifications.

A priori, it seems appealing to retain the integrity of the cost function and precede with the Battese and Coelli (1995) model whereby so-called environment factors or possible university characteristics enter as a set of covariates in the determination of the inefficiency term. Denoting these factors as $z_{r, i t}$, the inefficiency component is formulated as Eq. 2 follows:

$$
\mathrm{u}_{\mathrm{it}}=\beta_{0}+\sum_{\mathrm{r}} \beta_{\mathrm{r}} \mathrm{z}_{\mathrm{r}}{ }_{\mathrm{it}}+\mathrm{w}_{\mathrm{it}}
$$

where, $\mathrm{w}_{\mathrm{it}}$ is the random component with mean zero and variance 2 and $\mathrm{u}_{\mathrm{it}}$ have the truncated distribution with the mean being conditional on (2) and variance $\sigma_{u}^{2}$. Thus, this can be conveniently labeled the conditional mean model. In contrast, under the alternative Battese and Coelli (1992) model, the $z_{r, i t}$ directly enter and, therefore, transform the cost structure (1). Inefficiencies are then determined by Eq. 3:

$$
\mathrm{u}_{\mathrm{it}}=\mathrm{u}_{\mathrm{i}} \exp (-\eta(\mathrm{t}-\mathrm{T}))
$$

Here, if time varying inefficiency exists, then $\eta$ in Eq. 3 becomes the monotonic inefficiency increase $(\eta<0)$ or decrease $(\eta>0)$ over time. In this approach, the model can be labeled as the time varying decay model.

Under both model specifications, the university cost inefficiency is time varying and defined as exp $\left(\mathrm{u}_{\mathrm{it}}\right)$. It will, therefore, vary between zero and infinity. However, when universities are set in rank order by their academic year inefficiency scores, the conditional mean can and most likely will produce, different rank orderings, i.e., universities will likely shift about in annual rankings. Under the decay model specification, while individual universities can experience time varying inefficiencies, they will retain their rank status over different academic years. Thus, for comparative evaluations, in the empirical analysis to follow, rankings across model specifications will be calculated based on each university's mean inefficiency.

In empirical estimation, nearly all frontier studies use maximum likelihood estimation and the Battesse and Corra (1977) reparameterization whereby $\sigma^{2}=$

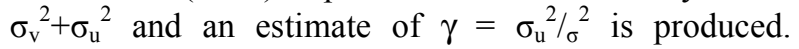
Gamma must lie between zero and one and can be used to test if the frontier is stochastic. If $\gamma=0$, then inefficiency effects are irrelevant and other econometric representations would be more appropriate. If $\gamma=1$, then random effects are absent and all cost deviations can be attributed to university operating inefficiencies.

Data: Survey data for individual universities is obtained from the Integrated Postsecondary Education Data System (IPEDS) as maintained by the U.S. Department of Education, National Center for Education Statistics. For each of the fifty states in the U.S., the university flagship was chosen and a panel data was assembled for the academic years 20052009. Four universities were omitted due to the lack of data. The variables constructed from IPEDS are provided in Table 1 along with their means and standard deviations.

The total Cost (C) measure corresponds to the university's total operating expenses. This is the measure used by other higher education cost studies that have employed IPEDS as the data source (Cohn et al., 1989; Koshal and Koshal, 1999; Sav, 2004; Lenton, 2008). The successes of past studies have also led to a general acceptance of variables that can reasonably proxy university outputs and input prices, including those listed in Table 1 for Undergraduate education output (U), Graduate education output (G), Research output (R) and the faculty Wage (W) as an input price. To the latter, the present study adds a capital price that is proxied by the universities year ending value of buildings $(\mathrm{K})$. The outputs and input prices are expected to carry positive effects in the cost frontier.

Three measures are included to capture the environment and characteristics related to the university. For the most part, these are assumed to be fairly fixed over the short-run and include student and faculty characteristics and a possible measure of the university's dependence on the government funding. As an indicator of student characteristics, included is the percentage of students whose tuition is funded under low income federally sponsored grants (LOWINC). Presumably, these students would more likely to have come from lower income, underfunded school districts and would be more academically at risk relative to higher income students that are ineligible for such grants. For a possible measure related to faculty characteristics, included is the percentage of faculty that are tenured (TENURE). Tenured faculty has met the teaching and scholarship standards adopted by faculty governance and the university administration. 
Am. J. of Economics and Business Administration 3 (4): 596-603, 2011

Table 1: Variable descriptions, means and standard deviations

\begin{tabular}{|c|c|c|c|}
\hline Variable & Description & Mean & SD \\
\hline$\overline{\mathrm{C}}$ & $\begin{array}{l}\text { Total academic } \\
\text { Year Cost, \$ }\end{array}$ & $1.21 \mathrm{E}+09$ & $9.90 \mathrm{E}+08$ \\
\hline $\mathrm{U}$ & $\begin{array}{l}\text { Undergraduate } \\
\text { credit hours produced }\end{array}$ & $5.92 \mathrm{E}+05$ & $3.09 \mathrm{E}+05$ \\
\hline G & $\begin{array}{l}\text { Graduate credit } \\
\text { hours produced }\end{array}$ & $1.25 \mathrm{E}+05$ & $1.05 \mathrm{E}+05$ \\
\hline $\mathrm{R}$ & $\begin{array}{l}\text { Research } \\
\text { grants produced }\end{array}$ & $2.70 \mathrm{E}+08$ & $2.36 \mathrm{E}+08$ \\
\hline W & $\begin{array}{l}\text { Faculty wage- } \$ \\
\text { average salary, }\end{array}$ & 82345.000000 & 11730.0000 \\
\hline K & $\begin{array}{l}\text { Capital price- } \\
\text { buildings value, } \$\end{array}$ & $1.14 \mathrm{E}+09$ & $8.45 \mathrm{E}+08$ \\
\hline LOWINC & $\begin{array}{l}\text { Low income } \\
\text { student grant enrollment (\%) }\end{array}$ & 18.76 .0000 & 7.45 .000 \\
\hline TENURE & Tenured faculty (\%) & 49.57 .0000 & 7.88 .000 \\
\hline GOVT & $\begin{array}{l}\text { Government } \\
\text { revenue source }(\%)\end{array}$ & 23.710000 & 9.74 .000 \\
\hline
\end{tabular}

The final measure is the percentage of university revenues that are derived from the combined sources of federal, state and local Governments (GOVT). The greater is that funding source, the less dependent is the university on private dollars, including, e.g., private philanthropy. In part, similar measures have been employed in the frontier analysis of primary and secondary education undertaken by Chakraborty and Poggio (2008) and in the English and Welsh university study by Stevens (2005). Presently, they are included without speculation as to how they would affect inefficiency in Eq. 2 or transform costs when included as a modification to the frontier in Eq. 1. That is, one could, for example, argue that a greater relative source of government funding improves efficiency by relieving universities from the need to allocate scarce resources to private fund raising activities. Others, of course, might argue that more government funding represents greater government relative to private ownership and, therefore, creates inefficiency through the removal of private market incentives. Overall, these effects remain to be empirically established.

\section{RESULTS AND DISCUSSION}

The maximum likelihood estimates are presented in Table 2 for the translog and Cobb-Douglas specifications under both inefficiency models. In all four cases, the likelihood ratios are statistically significant, thereby indicating the superiority of the frontier specification over ordinary least squares. Moreover, across all specification-model combinations, statistical significance of suggests that inefficiency plays a significant role in the operating costs of universities.
Table 2: University frontier maximum likelihood estimates

\begin{tabular}{|c|c|c|c|c|c|c|c|c|}
\hline \multirow[b]{2}{*}{ Coefficient } & \multicolumn{4}{|c|}{ Conditional mean model } & \multicolumn{4}{|c|}{ Time varying decay model } \\
\hline & \multicolumn{2}{|c|}{ t Translog } & \multicolumn{2}{|c|}{ Cobb-douglas } & \multicolumn{2}{|c|}{ Translog } & \multicolumn{2}{|c|}{ Cobb-douglas } \\
\hline$\alpha 0$ & -245.147 & $*-1.99$ & 0.081 & 0.08 & 2.280 & 0.04 & 0.107 & 0.09 \\
\hline$\alpha \mathrm{U}$ & 12.080 & $* 1.75$ & -0.001 & -0.02 & 13.222 & $* 3.03$ & 0.131 & $* 1.75$ \\
\hline$\alpha \mathrm{G}$ & -15.509 & $*-3.37$ & 0.207 & $* 6.89$ & -7.719 & $*-2.76$ & 0.102 & $* 2.91$ \\
\hline$\alpha \mathrm{R}$ & 11.358 & $* 3.08$ & 0.267 & $* 12.42$ & -0.128 & -0.05 & 0.288 & $* 7.20$ \\
\hline$\alpha \mathrm{W}$ & 21.551 & 0.82 & 0.226 & $* 1.82$ & -15.681 & -1.22 & 0.411 & $* 2.98$ \\
\hline$\alpha \mathrm{K}$ & 3.413 & 0.62 & 0.503 & $* 13.00$ & 5.440 & 1.49 & 0.427 & *7.12 \\
\hline$\alpha \mathrm{UU}$ & 0.067 & 0.36 & - & - & -0.349 & $*-2.36$ & - & - \\
\hline$\alpha \mathrm{GG}$ & -0.092 & -1.13 & - & - & -0.139 & $*_{-1.73}$ & - & - \\
\hline$\alpha \mathrm{RR}$ & -0.092 & $*-1.83$ & - & - & 0.064 & 1.51 & - & - \\
\hline$\alpha \mathrm{WW}$ & 0.825 & 0.53 & - & - & 1.894 & $* 2.37$ & - & - \\
\hline$\alpha \mathrm{KK}$ & 0.208 & $* 1.82$ & - & - & -0.005 & -0.05 & - & - \\
\hline$\alpha \mathrm{UG}$ & -0.150 & -0.78 & - & - & 0.470 & $* 3.02$ & - & - \\
\hline$\alpha \mathrm{UR}$ & -0.517 & $*-3.87$ & - & - & -0.574 & $*_{-5} .21$ & - & - \\
\hline$\alpha \mathrm{UW}$ & -1.551 & $*-2.02$ & - & - & -1.005 & $*-1.96$ & - & - \\
\hline$\alpha \mathrm{UK}$ & 0.737 & $* 3.28$ & - & - & 0.636 & $* 3.10$ & - & - \\
\hline$\alpha \mathrm{GR}$ & 0.335 & $* 2.81$ & - & - & 0.154 & $* 1.72$ & - & - \\
\hline$\alpha \mathrm{GW}$ & 2.001 & $* 3.75$ & - & - & 0.913 & $* 2.65$ & - & - \\
\hline$\alpha \mathrm{GK}$ & -0.448 & $*-2.92$ & - & - & -0.411 & $*-3.72$ & - & - \\
\hline$\alpha \mathrm{RW}$ & -0.557 & $*-1.71$ & - & - & -0.049 & -0.20 & - & - \\
\hline$\alpha \mathrm{RK}$ & 0.085 & 0.78 & - & - & 0.214 & $* 2.15$ & - & - \\
\hline$\alpha \mathrm{WK}$ & -1.556 & $*-2.33$ & - & - & -1.123 & $*-2.59$ & - & - \\
\hline$\beta$ LOWINC & 0.228 & $* 2.97$ & 0.142 & 1.26 & -0.036 & -1.01 & -0.042 & -1.01 \\
\hline$\beta$ TENURE & -0.073 & -0.57 & -0.576 & $*-2.09$ & -0.261 & $*-2.84$ & -0.331 & $*_{-3.23}$ \\
\hline$\beta$ GOVT & -0.256 & $*-3.76$ & -0.465 & $*-3.28$ & 0.001 & 0.03 & -0.054 & -1.40 \\
\hline$\beta 0$ & 0.534 & 0.94 & 3.175 & $* 2.70$ & - & - & - & - \\
\hline$\eta$ & - & - & - & - & -0.071 & -4.15 & -0.024 & -1.08 \\
\hline$\sigma 2$ & 0.019 & $* 3.240$ & 0.058 & $* 3.000$ & 0.384 & $* 7.27$ & 0.059 & $* 1.72$ \\
\hline$\gamma$ & 0.694 & $* 4.140$ & 0.930 & $* 29.180$ & 0.994 & *655.37 & 0.940 & $* 26.96$ \\
\hline LL & 135.130 & 107.591 & 206.930 & 183.439 & & & & \\
\hline LL Ratio & $* 50.950$ & 70.621 & $* 148.96 *$ & *184.497 & & & & \\
\hline
\end{tabular}

Note: $\mathrm{LL}=\mathrm{Log}$ Likelihood

In fact, the share inefficiency in the comprised error exceeds 0.90 in all estimates except the conditional mean transom model in which it is approximately 0.7 .

In general and as counseled by Greene (2003), the focus of stochastic frontier studies lies with the inefficiency estimates rather than the model parameters. That applies to the current inquiry. However, it can be noted that the three output coefficients and the two input prices generally carry the expected positive signs with statistical significance under both Cobb-Douglas estimates; the exception being the negative but statistically insignificant performance of undergraduate education in the conditional mean model. Given that the Cobb-Douglas coefficients are interpretable as elasticities, the findings indicate that research output has the largest cost effect while, as might be expected, capital investments carry somewhat largest cost implications relative to faculty wage increases. Of course, the results for individual coefficients in the transom specifications are not directly meaningful due to the nonlinear nature of the specification. Yet, the majority of coefficients entering the cost function does reach reasonable levels of statistical significance and indicate that there is complementarily between faculty wages and research output. More noteworthy are the differences in the effects of environmental factors or university characteristics on inefficiency. In particular, the results indicate that increases in the percentage of low income student enrollments have a positive and, therefore inefficiency increasing, effect in both the transom and Cobb-Douglas conditional mean estimates. 
Table 3: Inefficiency estimates by model, specification and academic years

Conditional mean model

Translog specification

Cobb-douglas specification

$\begin{array}{lllllllllll}\text { Year } & 05-06 & 06-07 & 07-08 & 08-09 & 05-09 & 05-06 & 06-07 & 07-08 & 08-09 & 05-09\end{array}$

\begin{tabular}{lllllllllll}
\hline Mean & 1.185 & 1.177 & 1.211 & 1.194 & 1.192 & 1.205 & 1.209 & 1.230 & 1.200 & 1.211
\end{tabular}

$\begin{array}{lllllllllll}\text { Median } & 1.152 & 1.150 & 1.173 & 1.171 & 1.162 & 1.125 & 1.136 & 1.135 & 1.114 & 1.133\end{array}$

$\begin{array}{llllllllll}\text { Minimum } 1.024 & 1.038 & 1.060 & 1.030 & 1.024 & 1.020 & 1.023 & 1.032 & 1.027 & 1.020\end{array}$

$\begin{array}{lllllllllll}\text { Maximum } 1.583 & 1.557 & 1.649 & 1.595 & 1.649 & 1.866 & 1.836 & 1.961 & 1.912 & 1.961\end{array}$

$\begin{array}{lllllllllll}\text { S.D. } & 0.134 & 0.121 & 0.146 & 0.143 & 0.136 & 0.200 & 0.197 & 0.225 & 0.206 & 0.206\end{array}$

Time varying decay model

$\begin{array}{lllllllllll}\text { Year } & 05-06 & 06-07 & 07-08 & 08-09 & 05-09 & 05-06 & 06-07 & 07-08 & 08-09 & 05-09\end{array}$

$\begin{array}{lllllllllll}\text { Mean } & 1.276 & 1.301 & 1.329 & 1.360 & 1.317 & 1.278 & 1.286 & 1.294 & 1.303 & 1.290\end{array}$

$\begin{array}{lllllllllll}\text { Median } & 1.217 & 1.234 & 1.253 & 1.275 & 1.242 & 1.226 & 1.232 & 1.239 & 1.245 & 1.235\end{array}$

$\begin{array}{lllllllllll}\text { Minimum } 1.015 & 1.016 & 1.017 & 1.018 & 1.015 & 1.017 & 1.018 & 1.018 & 1.019 & 1.017\end{array}$

$\begin{array}{llllllllll}\text { Maximum } 2.049 & 2.160 & 2.286 & 2.430 & 2.430 & 1.961 & 1.993 & 2.027 & 2.062 & 2.062\end{array}$

\begin{tabular}{lllllllllll} 
S.D. $\quad 0.252$ & 0.278 & 0.306 & 0.339 & 0.295 & 0.219 & 0.226 & 0.233 & 0.241 & 0.228 \\
\hline
\end{tabular}

Quite differently, the negative effect on costs consistently prevails in both specifications under the time varying decay model. However, only one of the four low income estimated effects reaches any reasonable level of statistical significance. In contrast, the tenured faculty coefficient is negative in all specifications and is statistically significant in three of the four. Counter to opponents of the tenure system in higher education, the findings suggest that tenure produces cost savings and efficiency improvements. Equally as interesting are the results pertaining to government funding. In the conditional mean results, increased government funding, increases university operating cost efficiency. Furthermore, its statistical weakness in the time varying decay cost function suggests that the level of government funding relative to private market funding does not affect the total cost of delivering the multitude of educational products.

Turning to the main thrust of the study, Table 3 presents the cost inefficiency scores for the group of flagship universities. The scores represent the extent to which these universities operate above the minimum cost frontier. The scores range from a minimum of $1.015-1.5 \%$ to a maximum of $2.43-143 \%$; both of which are obtained in the implementation of the transom specification under the decay model. That specification-model combination also produces the largest four-year 2005-09 mean, 1.317 and median, 1.242, inefficiency estimates and exhibits the greatest inefficiency variability. But it is the same transom specification but in combination with conditional mean model that results in the smallest 2005-09 mean inefficiency estimate of 1.192-19.2\%. When examining university performance in individual academic years, the transom conditional means estimates reveal that universities experienced a slight efficiency improvement (i.e., inefficiency score decrease) in both the 2006-07 and 2008-09 academic years. The Cobb-Douglas conditional mean estimates also show an efficiency improvement but confined to the single 2008-09 academic year.
Of course, the time varying decay model does not permit such variations due to the constraint imposed by the estimate of which presently produces annual inefficiency increases. Overall, comparing the results among the four different specifications and models, one is hard pressed to find any common ground or consistency in estimated inefficiencies. The variability in results indicate that inefficiency estimates are sensitive to the econometric specification of the underlying cost structure as well as the assumption regarding the inefficiency measurement and whether or not environmental and managerial factors enter as effects on university cost or effects on university inefficiency.

The above also suggests that attempts to evaluate the status of individual university performances through inefficiency rankings are likely to produce outcomes that are equally sensitive to modeling choices. Table 4 offers some insights into the degree of that sensitivity. Universities are presented in rank order according to their mean inefficiency as calculated from the four possible inefficiency estimates. As a result, compared to Table 3, the inefficiency range is compressed with the difference between the most inefficient score obtained by Utah being $87 \%$ above lowest inefficiency score at the University of Maryland. The mean and median of these inefficiency scores is 1.25 and 1.19 , respectively. The four columns following the university name present the individual university rank achieved under each specification-model combination. Examining the alternative rankings, one observes some significant movement among the ranks for individual universities. To provide an indication of the rank movement for a given university, the Min-Max rank calculation shows, e.g., that the 13 th overall ranked University of Oregon moves 30 ranked positions; from 36 th under the transom conditional mean model to 6th under the transom decay model. But Oregon is relatively settled down in three of the rankings and as the last column shows, it has an average rank of 16th that is not much different than its overall 16th ranked position. Other universities exhibit greater rank volatility but it exists between cost specifications. For example, overall 8th ranked Mississippi, is ranked approximately at the median under both the conditional mean model rankings (24 and 20th) and then gets near the top rank in both of the decay model rankings (4th and 2nd). Thus, its Min-Max movement is across 22 ranks but on average its 13 th rank is not that different from its overall mean score rank. At the other extreme are those institutions that exhibit strong rank stability. Utah maintains the same 46th rank position regardless of the cost-inefficiency model. In this respect, the most inefficiently ranked universities tend maintain their rankings irrespective of the model formulation. 
Am. J. of Economics and Business Administration 3 (4): 596-603, 2011

Table 4: University inefficiency rankings

\begin{tabular}{|c|c|c|c|c|c|c|c|c|}
\hline \multirow[b]{2}{*}{$\begin{array}{l}\text { Mean } \\
\text { rank }\end{array}$} & \multirow[b]{2}{*}{$\begin{array}{l}\text { Mean } \\
\text { score }\end{array}$} & \multirow[b]{2}{*}{ University } & \multicolumn{2}{|c|}{ Conditional } & \multicolumn{2}{|l|}{ Decay } & \multicolumn{2}{|l|}{ Min } \\
\hline & & & $\begin{array}{l}\mathrm{TL} \\
\text { rank }\end{array}$ & $\begin{array}{l}\mathrm{CD} \\
\text { rank }\end{array}$ & $\begin{array}{l}\mathrm{TL} \\
\text { rank }\end{array}$ & $\begin{array}{l}\mathrm{CD} \\
\text { rank }\end{array}$ & $\begin{array}{l}\text { Minus } \\
\max \end{array}$ & $\begin{array}{l}\text { Mean } \\
\text { rank }^{\mathrm{a}}\end{array}$ \\
\hline 1 & 1.033 & Maryland & 4.00 & 1.00 & 1.00 & 1.00 & -3 & 2 \\
\hline 2 & 1.039 & South carolina & 1.00 & 5.00 & 5.00 & 3.00 & -4 & 4 \\
\hline 3 & 1.058 & Alaska & 7.00 & 3.00 & 7.00 & 6.00 & -4 & 6 \\
\hline 4 & 1.071 & Florida & 19.00 & 4.00 & 3.00 & 7.00 & -16 & 8 \\
\hline 5 & 1.081 & New hampshire & 12.00 & 2.00 & 14.00 & 5.00 & -12 & 8 \\
\hline 6 & 1.084 & SUNY & 5.00 & 8.00 & 2.00 & 15.00 & -13 & 8 \\
\hline 7 & 1.084 & Louisiana & 22.00 & 14.00 & 9.00 & 4.00 & -18 & 12 \\
\hline 8 & 1.086 & Mississippi & 24.00 & 20.00 & 4.00 & 2.00 & -22 & 13 \\
\hline 9 & 1.089 & Nevada & 6.00 & 26.00 & 10.00 & 9.00 & -20 & 13 \\
\hline 10 & 1.100 & South dakota & 23.00 & 19.00 & 8.00 & 8.00 & -15 & 15 \\
\hline 11 & 1.106 & West virginia & 17.00 & 13.00 & 11.00 & 10.00 & -7 & 13 \\
\hline 12 & 1.116 & Arizona & 2.00 & 7.00 & 16.00 & 18.00 & -16 & 11 \\
\hline 13 & 1.122 & Oregon & 36.00 & 12.00 & 6.00 & 11.00 & -30 & 16 \\
\hline 14 & 1.126 & Georgia & 3.00 & 9.00 & 19.00 & 16.00 & -16 & 12 \\
\hline 15 & 1.127 & Alabama & 10.00 & 22.00 & 13.00 & 19.00 & -12 & 16 \\
\hline 16 & 1.128 & Hawaii & 8.00 & 25.00 & 12.00 & 22.00 & -17 & 17 \\
\hline 17 & 1.145 & Arkansas & 15.00 & 18.00 & 21.00 & 12.00 & -9 & 17 \\
\hline 18 & 1.147 & Wyoming & 11.00 & 10.00 & 22.00 & 17.00 & -12 & 15 \\
\hline 19 & 1.152 & Idaho & 20.00 & 6.00 & 23.00 & 14.00 & -17 & 16 \\
\hline 20 & 1.164 & Wisconsin & 16.00 & 24.00 & 17.00 & 26.00 & -10 & 21 \\
\hline 21 & 1.165 & Washington & 37.00 & 16.00 & 15.00 & 13.00 & -24 & 20 \\
\hline 22 & 1.185 & Massachusetts & 14.00 & 21.00 & 25.00 & 27.00 & -13 & 22 \\
\hline 23 & 1.190 & North Dakota & 25.00 & 29.00 & 20.00 & 21.00 & -9 & 24 \\
\hline 24 & 1.197 & Texas & 26.00 & 11.00 & 28.00 & 23.00 & -17 & 22 \\
\hline 25 & 1.199 & Kansas & 9.00 & 23.00 & 27.00 & 29.00 & -20 & 22 \\
\hline 26 & 1.222 & Rhode Island & 28.00 & 30.00 & 24.00 & 24.00 & -6 & 27 \\
\hline 27 & 1.223 & Tennessee & 18.00 & 32.00 & 26.00 & 31.00 & -14 & 27 \\
\hline 28 & 1.234 & North Carolina & 21.00 & 33.00 & 18.00 & 36.00 & -18 & 27 \\
\hline 29 & 1.238 & Rutgers & 32.00 & 17.00 & 35.00 & 25.00 & -18 & 27 \\
\hline 30 & 1.246 & Oklahoma & 35.00 & 27.00 & 32.00 & 28.00 & -8 & 31 \\
\hline 31 & 1.255 & Illinois & 31.00 & 28.00 & 33.00 & 32.00 & -5 & 31 \\
\hline 32 & 1.281 & Indiana & 30.00 & 35.00 & 29.00 & 33.00 & -6 & 32 \\
\hline 33 & 1.282 & Minnesota & 34.00 & 31.00 & 34.00 & 34.00 & -3 & 33 \\
\hline 34 & 1.289 & Nebraska & 27.00 & 37.00 & 30.00 & 35.00 & -10 & 32 \\
\hline 35 & 1.301 & Vermont & 40.00 & 38.00 & 36.00 & 20.00 & -20 & 34 \\
\hline 36 & 1.313 & Connecticut & 13.00 & 15.00 & 42.00 & 30.00 & -29 & 25 \\
\hline 37 & 1.357 & Maine & 41.00 & 34.00 & 37.00 & 38.00 & -7 & 38 \\
\hline 38 & 1.370 & Montana & 43.00 & 39.00 & 31.00 & 37.00 & -12 & 38 \\
\hline 39 & 1.479 & Ohio State & 44.00 & 36.00 & 41.00 & 39.00 & -8 & 40 \\
\hline 40 & 1.498 & Missouri & 29.00 & 42.00 & 38.00 & 42.00 & -13 & 38 \\
\hline 41 & 1.524 & Virginia & 33.00 & 40.00 & 45.00 & 40.00 & -12 & 40 \\
\hline 42 & 1.563 & Iowa & 38.00 & 43.00 & 39.00 & 43.00 & -5 & 41 \\
\hline 43 & 1.575 & Michigan & 42.00 & 41.00 & 43.00 & 41.00 & -2 & 42 \\
\hline 44 & 1.640 & Kentucky & 39.00 & 44.00 & 40.00 & 44.00 & -5 & 42 \\
\hline 45 & 1.792 & New Mexico & 45.00 & 45.00 & 44.00 & 45.00 & -1 & 45 \\
\hline 46 & 1.931 & Utah & 46.00 & 46.00 & 46.00 & 46.00 & 0 & 46 \\
\hline \multirow{4}{*}{\multicolumn{2}{|c|}{ Correlations }} & Conditional TL & 1.00 & & & & & \\
\hline & & Conditional CD & 0.73 & 1.00 & & & & \\
\hline & & Decay TL & 0.69 & 0.76 & 1.00 & & & \\
\hline & & Decay CD & 0.65 & 0.86 & 0.89 & 1.00 & & \\
\hline
\end{tabular}

Note: $\mathrm{TL}=$ Translog and $\mathrm{CD}=$ Cobb-Douglas. (a) Rounded to whole numbers

The same relationship tends to hold among the most efficient and, therefore, top ranked universities. Number one overall ranked Maryland maintains that status in three of the four rankings and likewise takes the highest average rank. The same efficiency stability holds with the 2nd and 3rd ranked South Carolina and Alaska.

Correlations between the various model rankings are presented at the bottom of Table 4 . The weakest correlations occur between the rankings produced under the transom conditional mean model and all other models. Even the correlation between the two transom rankings under the two different inefficiency models is only 0.69 . The strongest correlation of 0.89 occurs under the decay model between the Cobb-Douglas and transom rankings. In sum, the correlations suggest that relative to the conditional mean model, the inefficiency rankings produced under the time varying decay model are less sensitive to the econometric cost specification.

\section{CONCLUSION}

This study investigated the extent to which stochastic cost frontier inefficiency estimates can vary according to the formulation of the underlying cost structure in combination with the choice of an inefficiency model. Empirical application was made to the U.S. higher education public flagship universities using panel data covering four academic years, 200509 . University cost inefficiencies were estimated under a transom and Cobb-Douglas specification in combination with a conditional mean inefficiency model that placed university specific characteristics in the inefficiency component and a time varying decay model that assumed such characteristics alter university cost structures. The inefficiency estimates are believed to be the first of their kind in application to the flagship group of U.S. publicly owned, tax supported universities.

Estimated mean inefficiencies varied from 1.1921.317 and, therefore, suggest that universities are on average operating from $19.2-31.7 \%$ above their minimum cost frontier. Both these estimates arose under the translog specification with the low score occurring under the conditional mean model. The higher estimate was generated from the transom time varying decay model where there also occurred both the minimum 1.015 and maximum 2.430 university inefficiency scores. Inefficiency estimates under the Cobb-Douglas specification were somewhat narrower in range with mean scores at 1.211 and 1.290 for the conditional mean and decay models, respectively. Under the decay model, university cost inefficiencies increased with each academic year. In contrast, under the conditional mean model, there is evidence that universities produced efficiency improvements in both the 2006-07 and 2008-09 academic years. Overall, there appears to be little consistency in the inefficiency estimates across the four cost-inefficiency models. However, inefficiency rankings for individual universities does some degree of consistency in that the universities obtaining the most inefficient scores and those obtaining the most efficient scores and, therefore, ranks tend to maintain their rank status regardless of the stochastic model. Yet, there are universities that are subject to large differences in inefficiency estimates 
and as a result are flung across many ranks depending upon the model specification. But, again, universities at the top and bottom of the rankings, exhibit little to no rank movements. University mean inefficiency scores were calculated and used to provide an overall ranking. Based on this calculation, the grand mean inefficiency for the flagship universities was 1.25. Interestingly, this compares to Stevens (2005) mean inefficiency of 1.26 for English and Welsh universities.

Before closing, it is also of note that the in route to the inefficiency estimates, there was empirical evidence produced to suggest that university faculty tenure produces cost efficiency gains along with cost savings. In addition, increased government funding of universities was similarly found improve the cost efficiency of universities but carry no significant effects on overall educational operating costs. The results tend to provide support for advocates of the tenure system and weaken arguments pertaining to the potential inefficiencies in the government provision of higher education.

In sum, the findings support the notion that stochastic frontier estimates of university cost inefficiencies and subsequent inefficiency rankings are sensitive to the cost and inefficiency model specifications. In the present study, that conclusion is derived from the application to publicly owned flagship universities in the U.S. and represents the first inquiry into that specific group of universities. If applied as rigorously to other types of universities, other countries, or other industries, then there may not be the same sensitivities to modeling implementations. Yet, the findings presented in this study suggest that in the absence of testing for such sensitivities, the confidence placed upon the empirical results can be subject to question.

\section{REFERENCES}

Abbott, M. and C. Doucouliagos, 2009. Competition and efficiency: Overseas students and technical efficiency in Australian and New Zealand universities. Educ. Econ., 17: 31-57. DOI: 10.1080/09645290701773433

Aigner, D., C.A.K. Lowell and P. Schmidt, 1977. Formulation and estimation of stochastic frontier production function models. J. Econ., 6: 21-37. DOI: 10.1016/0304-4076(77)90052-5

Barros, C.P. and F.P. Alves, 2005. Efficiency in crime prevention: A case study of the lisbon precincts. Int. Adv. Econ. Res., 11: 315-328. DOI: 10.1007/s11294-005-6660-z

Barros, C.P. and S. Leach, 2007. Technical efficiency in the English football association premier league with a stochastic cost frontier. Applied Econ. Lett., 14: 731-741. DOI: 10.1080/13504850600592440
Battese, G.E. and T.J. Coelli, 1992. Frontier production functions, technical efficiency and panel data: With application to paddy farmers in India. J. Produ. Anal., 3: 153-169. DOI: 10.1007/BF00158774

Battese, G.E. and T.J. Coelli, 1995. A Model for technical inefficiency effects in a stochastic frontier production function for panel data. Empirical Econ., 20: 325-332. DOI: 10.1007/BF01205442

Battesse, G.E. and G.S. Corra, 1977. Estimation of production frontier model: With application to the pastoral zone of eastern Australia. Aus. J. Agric. Econ., 21: 169-179.

Bradford, W.D., A.N. Kleit, M.A. Krousel-Wood and R.N. Re, 2001. Stochastic frontier estimation of cost models within the hospital. Rev. Econ. Stat., 83: 302-309. DOI: 10.1162/00346530151143833

Chakraborty, K. and J. Poggio, 2008. Efficiency and equity in school funding: A case study for Kansas. Int. Adv. Econ. Res., 14: 228-241. DOI: 10.1007/s11294-008-9137-z

Coelli, T., 2005. An Introduction to Efficiency and Productivity Analysis. 2nd Edn., Springer, New York, ISBN: 0387242651, pp: 349.

Coelli, T., S. Perelman and E. Romano, 1999. Accounting for environmental influences in stochastic frontier models: With application to international airlines. J. Produ. Anal., 11: 251-273. DOI: $10.1023 / \mathrm{A}: 1007794121363$

Cohn, E., S.L. Rhine, W. Rhine and M.C. Santos, 1989. Institutions of higher education as multi-product firms: Economies of scale and scope. Rev. Econ. Stat., 71: 284-290. DOI: 10.2307/1926974

Cummins, J.D. and M.A. Weiss, 1993. Measuring cost efficiency in the property-liability insurance industry. J. Bank. Finan., 17: 463-481. DOI: 10.1016/0378-4266(93)90046-G

Farsi, M. and M. Filippini, 2004. An empirical analysis of cost efficiency in non-profit and public nursing homes. Ann. Public Cooperative Econ., 75: 339365. DOI: $10.1111 / \mathrm{j} .1467-8292.2004 .00255 . x$

Fried, H.O., C.A.K. Lovell, S.S. Schmidt, 2008. The Measurement of Productive Efficiency and Productivity Growth. 1st Edn., Oxford University Press, New York, ISBN-10: 0199884803, pp: 656.

Fujii, A., 2001. Determinants and probability distribution of inefficiency in the stochastic cost frontier of Japanese hospitals. Applied Econ. Lett., 8: 807-812. DOI: 10.1080/13504850110046507

Greene, W.H., 2003. Econometric Analysis. 5th Edn., Prentice Hall, New York, ISBN: 0130661899, pp: 1026. 
Huang, T. and M.H. Wang, 2001. Measuring scale and scope economies in multiproduct banking? A stochastic frontier cost function approach. Applied Econ. Lett., 8: 159-162. DOI: $10.1080 / 13504850150504513$

Izadi, H., G. Johnes, R. Oskrochi and R. Crouchley, 2002. Stochastic frontier estimation of a CES cost function: The Case of higher education in Britain. Econ. Edu. Rev., 21: 63-71. DOI: 10.1016/S02727757(00)00044-3

Johnes, G. and J. Johnes, 2009. Higher education institutions' costs and efficiency: Taking the decomposition a further step. Econ. Educ. Rev., 28: 107-113. DOI: 10.1016/j.econedurev.2008.02.001

Knittel, C.R., 2002. Alternative regulatory methods and firm efficiency: Stochastic frontier evidence from the U.S. Electricity Industry. Rev. Econ. Stat., 84: 530-540. DOI: 10.1162/003465302320259529

Koshal, R. and M. Koshal, 1999. Economies of scale and scope in higher education: A case of comprehensive universities. Econ. Educ. Rev., 18: 269-277. DOI: 10.1016/S0272-7757(98)00035-1

Kumbhakar, S.C. and C.A.K. Lovell, 2003. Stochastic Frontier Analysis. 1st Edn., Cambridge University Press, New York, ISBN: 0521666635, pp: 344.

Kumbhakar, S.C., 1991. The measurement and decomposition of cost-inefficiency: The translog cost system. Oxford Econ. Papers, 43: 667-683.
Kumbhakar, S.C., S. Ghosh and J.T. McGuckin, 1991. A Generalized production frontier approach for estimating determinants of inefficiency in U.S. dairy farms. J. Bus. Econ. Stat., 279-286. DOI: $10.2307 / 1391292$

Lenton, P., 2008. The cost structure of higher education in further education colleges in England. Econ. Educ. Rev., 27: 471-482. DOI: 10.1016/j.econedurev.2007.05.003

McMillan, M.L. and W.H. Chan, 2006. University efficiency: A comparison and consolidation of results from stochastic and non-stochastic methods. Educ, Econ., 14: 1-30. DOI: 10.1080/09645290500481857

Meeusen, W. and J. Broech, 1977. Efficiency estimation from cobb-douglas production functions with composed error. Int. Econ. Rev., 18: 435-444. DOI: $10.2307 / 2525757$

Mulatu, A. and N. Crafts, 2005. Efficiency among private railway companies in a weakly regulated system: The case of Britain's railways in 18931912. Nicholas F.R. Crafts.

Sav, G.T., 2004. Higher education costs and scale and scope economies. Applied Econ., 36: 607-614. DOI: $10.1080 / 0003684042000217643$

Stevens, P.A., 2005. A stochastic frontier analysis of English and welsh universities. Educ. Econ., 13: 355-374. DOI: 10.1080/09645290500251581 